\title{
AleXander (SANDOR) SzAKats: A TRIBUTE
}

\author{
Martin Vranken*
}

\section{INTRODUCTION}

I first met with Alexander Szakáts towards the end of 1985. Only a few months earlier I had stepped off the plane as a new immigrant from Belgium. Our meeting place was The Buttery, one of Wellington's more agreeable coffee houses at the time. Over lunch we discussed the Lange Government's Green Paper on Industrial Relations: A Framework for Review (Department of Labour, Government Printer, Wellington, 1985). This document was to form the basis for a thorough revamp of New Zealand's system for the regulation of industrial relations - including its traditional pillars of compulsory conciliation and arbitration. Professor Szakáts generously donated his time to answer the many questions this comprehensive government text had triggered in my mind.

Since then we went back to The Buttery on more than one occasion and it became a quasi-regular meeting place. Through these meetings I formed a picture of Alexander Szakáts as a most charming man, very well-mannered and always willing to assist in my grappling with the new labour law environment. He was also a very private person, though, and only reluctantly would he volunteer information about his personal background. It was after being given a copy of his unpublished manuscript entitled Suspected Spy to Respected Scholar (Wellington, 1992) that the full magnitude of his escape from communist terror in Hungary and in the former Yugoslavia became clear to me. And it is this personal account for family and friends that has provided the basis for the tribute below.

\section{THE PRE-NEW ZEALAND PERIOD}

Sandor Szakáts was born in Budapest on 14 February 1915 as the second child in a family of three. His parents were educated people. His father, who trained as a lawyer, first worked as a civil servant but later went into private practice. The family, with roots in the nobility, was comfortable financially. Childhood seemed to have been a generally uneventful period. Even the forced separation from his parents in the aftermath of World

* Associate Professor and Reader, Faculty of Law, The University of Melbourne. 
War One was viewed as a happy occasion and the prolonged stay with his godmother remembered as an enjoyable holiday.

Szakáts clearly was an academically gifted student with wide-ranging interests. In 1940 he graduated Doctor in Political Science with a dissertation on Plato's and Aristotle's ideas about the state. A Dr Juris degree was awarded in 1942 following the successful defense of a thesis comparing limited liability (private) companies under German (GmbH) and Hungarian (Kft) law. All this was achieved against the backdrop of the Second World War and notwithstanding the interruption of his university studies as a result of being drafted for military service in 1939.

Particularly traumatic was the post war era. Hungary, having sided with the Germans, came under Soviet control. For reasons that are not elaborated upon in Suspected Spy to Respected Scholar, Dr Szakáts was considered a "reactionary" by the new political regime. (I have since been told by a close friend of his that it was enough to have been in the army and not to have joined the Communist party to acquire this status.) At first this merely (!) led to a practicing certificate being refused. Next came an order to report to the public authorities on a weekly basis as well as the need to avoid public places for fear of being apprehended. Marked a "class enemy" the general feeling was one of having to live as a second class citizen.

In 1948 his brother was arrested and fears grew that his own capture by the Hungarian political police (the AVO, the local equivalent of the Soviet KGB) would only be a matter of time. Thus Dr Szakáts fled south, towards Tito's supposedly friendly Yugoslavia. This turned out to be a serious miscalculation as the next twelve months were spent in various forced labour camps run by the Yugoslav political police (the UDBA). The period of June 1949 - June 1950, then, was the bleakest of all his life and the detail of his treatment during that time far too gruesome and distressing to be recalled here.

Dr Szakáts eventually managed to escape to Greece in June 1950 where he was put in a refugee camp near Athens. Because of his language skills - Hungarian, reasonably good German, some Serbian, Greek, and conversational English - he was asked to act as an interpreter for the New Zealand selection committee screening applicants for emigration. This in turn led to his own departure for New Zealand on the "Goya". The ship's arrival in Wellington harbour on a cold and wet day in August 1951 is vividly remembered, albeit not without some apprehension: "At first sight the promised land did not seem cheerful and welcoming." (Suspected Spy to Respected Scholar, page 83).

\section{HUMBLE BEGINNINGS}

Immediately upon arriving in New Zealand Dr Szakáts was bused to yet another camp, only this time it was to be one for displaced persons near Pahiatua. While there was no question of having to perform forced labour, the total lack of privacy as well as having to 
sleep in big dormitories and line up for food at meal times provided a strong incentive to return to a normal life as soon as possible. Because his Hungarian university degrees were not recognised, this initially meant taking a job as a book-keeper in the local garage. The move to a clerical position with Shell at Miramar (Wellington) in March 1952, together with employment as a casual storeman on weekends, provided somewhat greater financial reward.

But requalifying as a (New Zealand) lawyer was always at the forefront of his mind. Dr Szakáts enrolled as a law student of Victoria College at the University of New Zealand (as it then was) in 1953. His LLB was awarded in 1956; admission to practice followed in 1957. Law study was undertaken on a part-time basis in those days with classes being held early mornings and in the evening. To avoid having to commute - one hour by tram - from Miramar, Alexander Szakáts left Shell and joined the civil service, working for the Department of Maori Affairs as a basic grade clerk. Upon graduation he was promoted to legal officer and later, in 1958, appointed a district solicitor with the Lands and Survey Department. And, in between, somehow even time was found to marry and start a family!

At the instigation of Bruce Carran, a friend from his student years, Dr Szakáts started teaching commercial law to accountancy students at the Wellington Technical College (later the Polytechnic) on a part-time basis. In 1965 followed an appointment as Senior Lecturer at the Commerce Faculty (Accountancy Department) of Victoria University. That is when he resigned from the public service to embark upon, as it turned out, an illustrious academic career in his adopted country.

\section{ACADEMIC CAREER}

Professor Szakáts was 36 when he first arrived in New Zealand. He was in his early 40s by the time he had re-qualified as a lawyer. He was first appointed to a full-time university position at the age of 50. A mere seven years later he was offered the (then) second chair in law at Otago University. His publication record is equally impressive. Only some of his more influential writings will be highlighted here. Not surprisingly, especially in light of the above personal data, most of these major works have been produced when their author was in his 60 s and even 70 s.

\section{INTRODUCTION TO THE LAW OF EMPLOYMENT}

Even though his earliest scholarly output dealt with various aspects of commercial law, Professor Szakáts is best known for his writings on labour law. Pride of place takes Introduction to the Law of Employment of which three editions were published through Butterworths (Wellington) in 1975, 1981, and 1988, respectively. The third edition received the J F Northey Memorial Book Prize from the Legal Research Foundation. 
Prior to Introduction to the Law of Employment, existing publications in the field tended to focus almost exclusively on collective aspects of New Zealand labour law, then generally referred to as industrial law or industrial relations law, and covering - often in intricate detail - the legal regulation of trade unions as well as the traditional system of compulsory conciliation and arbitration for the resolution of industrial disputes. These industrial disputes were understood to mean collective disputes, either as between various unions or as between a union, as the collective representative of the workers, and one or more employers. Individual labour law, or employment law, on the other hand used to be neglected. The common law of master and servant was simply accepted to govern most aspects of the individual employer-employee relationship, without any attempt to fuse, or at least reconcile, statutory and common law. A good example in this regard is the (at the time) leading text on Industrial Law in New Zealand by Mathieson (Sweet \& Maxwell, Wellington, 1970).

Szakáts' Introduction to the Law of Employment consciously takes the individual employment relationship as its principal object, not by way of a reactionary, conservative, and anti-union reflex as some industrial relations academics would portray things, but rather because Szakáts correctly identified an emerging need for a hands-on discussion of the rights and obligations of individual employees and employers. This need was itself the result of legislative changes put in train as early as 1970, in particular the introduction of a statutory personal grievance procedure for the handling of disputes between employer and employee.

\section{DISMISSAL AND REDUNDANCY PROCEDURES}

Personal grievances are essentially, but not exclusively, about dismissal disputes. Dismissal and Redundancy Procedures (Butterworths, Wellington) was the first text on the law and procedures relating to the termination of employment in New Zealand. As such the book has proved invaluable to practitioners and academic scholars alike. Its first edition, published in 1985, was written in collaboration with Margaret Mulgan (then at Otago University). The second edition (with a contribution by myself) appeared five years later so as to take account of considerable statutory change during the intervening years in particular, the Labour Relations Act 1987, the State Owned Enterprises Act 1986 and the State Sector Act 1988. Further legislative reform, embodied in the Employment Contracts Act 1991, necessitated the writing of a Supplement in 1991.

\section{MAZENGARB'S INDUSTRIAL LAW AND INDUSTRIAL LAW BULLETIN}

New Zealand's major loose-leaf service to record recent developments in labour law has long been Mazengarb's Industrial Relations and Industrial Law in New Zealand, commonly known as Mazengarb's. This multi-volume publication was edited by Professor Szakáts for some fifteen years. Throughout that period he must have spent numerous hours 
painstakingly collecting legislative and judicial data, reading, summarising and integrating the new material with the existing body of law. But the net result was a fabulously annotated set of labour laws and a textbook in its own right.

In 1981 (the same year of obtaining his Emeritus Professorship) Szakáts also became the founding editor of Mazengarb's Industrial Law Bulletin. Circulated more frequently - eight times a year - than the larger Mazengarb's, the Bulletin set out to serve as an advance notice of the former. Over time, however, the Bulletin acquired a life - and considerable standing - of its own as it became New Zealand labour lawyers' first port of call for recent (essentially case law) developments. Interestingly, it is through reading the editorials accompanying each issue of the Bulletin that its author's sense of humour, in addition to a most perceptive mindset, is revealed. When he retired from the editorship in 1991 at the age of 76, it took a team of six people - a mixture of academics and practitioners - to continue his work!

\section{JOURNAL ARTICLES}

Through his books Professor Szakáts clearly put labour law "on the map" in New Zealand, and his pioneering role as regards the individual labour law dimension in particular must be commended. Over a period that spans some 35 years, Szakáts also produced dozens of articles and notes in academic journals and periodicals for legal professionals, ranging from the world-renowned International and Comparative Law Quarterly to the more domestic New Zealand Law Journal. Here a common theme or approach is harder to detect.

There is, of course, the comparative angle. And it would indeed seem only natural for someone with a civil law background but working in a common law environment to display an interest in comparative law. It will be recalled that his Hungarian law thesis involved a comparison of German and Hungarian approaches to the regulation of limited liability companies. Upon his appointment to a chair at Otago Professor Szakáts set up a new course in comparative law, but student interest appears to have been limited. Several of his published articles also look beyond the national (New Zealand) scene including, in particular, contributions on compulsory union membership ("Compulsory Unionism: A Strength or Weakness? The New Zealand System Compared with Union Security Agreements in Great Britain and the United States" (1972) 10 Alb L Rev 313); on industrial democracy ("Workers' Participation in Management: The German Experience" (1974) 16 Journal of Industrial Relations 29); on employee protection against dismissal ("FW Guest Memorial Lecture: Comparative Law and Job Security" (1974) 3 Otago LR 137; and even a review article on "Contractual Remedies in Asian Countries" (1978) 26 Am J Comp L 109.

It is fascinating to see such articles written in the 1970s. Labour law, as a field beyond industrial relations law, was at that stage a newly developing academic discipline in New 
Zealand, and a cross-national comparison of labour laws was virtually non-existent. (A notable exception is Alex Frame's 1970 article on worker participation published in the Victoria University of Wellington Law Review.) Besides, it was commonly thought that labour law did not lend itself easily to cross-fertilisation anyway because of the need to take into account the broader context within which a particular legal rule operates. As the great Sir Otto Kahn-Freund reminds us, this constraint has particular relevance in a labour law setting. (O Kahn-Freund "On Uses and Misuses of Comparative Law" (1974) 37 MLR 1.) Since then the value of comparative labour law has become more fully accepted. Szakáts was a forerunner in this field, and his interest in comparative law continued right up to the end. He was a founding member of the New Zealand Association for Comparative Law (1995) and a regular contributor to its yearbooks.

Professor Szakáts passed away on 1 July 2001. I miss him as a person and as a friend. His writings, however, provide a lasting record of an impressive scholarly contribution to the law in New Zealand. 